\title{
Alkali granite-syenite-carbonatite association in Munnar Kerala, India; implications for rifting, alkaline magmatism and liquid immiscibility
}

\author{
N G K NAIR, M SANTOSH and P K THAMPI \\ Centre for Earth Science Studies, P.B. No. 2235, Sasthamangalam, Trivandrum 695010, \\ India \\ MS received 23 July 1983; revised 23 December 1983
}

\begin{abstract}
Occurrence of carbonatite is reported from the Munnar area, Kerala, where an alkali granite-syenite-carbonatite association is seen emplaced along the intersection zone of the Attur and Kerala fault-lineaments. The carbonatites are of two varieties, a calcite-rich sovite and a very coarse grained, calcite and dolomite bearing alvikite. Higher levels of $\mathrm{SiO}_{2}$, $\mathrm{Al}_{2} \mathrm{O}_{3}$ and $\mathrm{CaO}$ are characteristic of these as compared to the composition of typical carbonatites. The transition element levels are high whereas the incompatible elements show lower values. The low Sr values, lower amount of apatite and absence of rare metal minerals preclude a primary carbonatite magma. The associated syenite and alkali granite have higher $\mathrm{K}_{2} \mathrm{O}, \mathrm{K}_{2} \mathrm{O} / \mathrm{Na}_{2} \mathrm{O}, \mathrm{K} / \mathrm{Rb}, \mathrm{K} / \mathrm{Ba}$ and transition element levels. Petrochemical features suggest the rock association to be a result of separation of an immiscible fraction of less viscous carbonate liquid during cooling and ascent from a more viscous polymerized alkali silicate phase. The pre-requisites for melt equilibration and liquid immiscibility were achieved through volatile degassing related to crustal warping and rifting. The unique alkaline association of Munnar, which shows spatial relationships with deep-seated faults as well as a probable triplepoint junction, is suggested to be a signature of late Precambrian alkaline magmatism which manifested in the Indian shield as a precursor to the rifting of the continental margin.
\end{abstract}

Keywords. Alkali granite-syenite-carbonatite; geochemistry; petrogenesis; alkaline silicate magma; liquid immiscibility; rifting.

\section{Introduction}

Alkaline rock associations, especially carbonatite complexes, have been a topic of interest for geologic, tectonic and experimental petrologic investigations the world over. In India, the Sevathur, Jokipatti, Newania and Bhinder complexes occurring in Precambrian settings and the Amba Dongar complex of Tertiary age have been studied in detail (Deans and Powell 1968; Phadke and Jhingran 1968; Sukheswala and Udas 1964; Udas and Krishnamurthy 1970; Borodin et al 1971). The present study reports the occurrence of carbonatite in the Kerala region which shows a unique genetic association with syenite and alkali granite. The study also attempts at petrogenetic considerations based on geochemical data and emphasises a rift-controlled alkaline magmatism in this part of the Indian continent during late Precambrian times as revealed by tectonic and geochronologic considerations.

\section{Geologic setting}

The alkali granite, syenite and carbonatite are emplaced within Precambrian gneisses of Munnar area in Kottayam district, Kerala (figure 1). The complex is spatially related to 
the inter-section zone of the NE-SW trending Attur lineament and the NW-SE trending Kerala lineament (figure 2) and occurs within the Anamalai-Palni-Cardamom massif (Katz 1978).

The alkali granite is exposed as an E-w trending irregular body (figure 1) and is traversed by pegmatites, aplites and quartz veins of varying dimensions (Nair et al

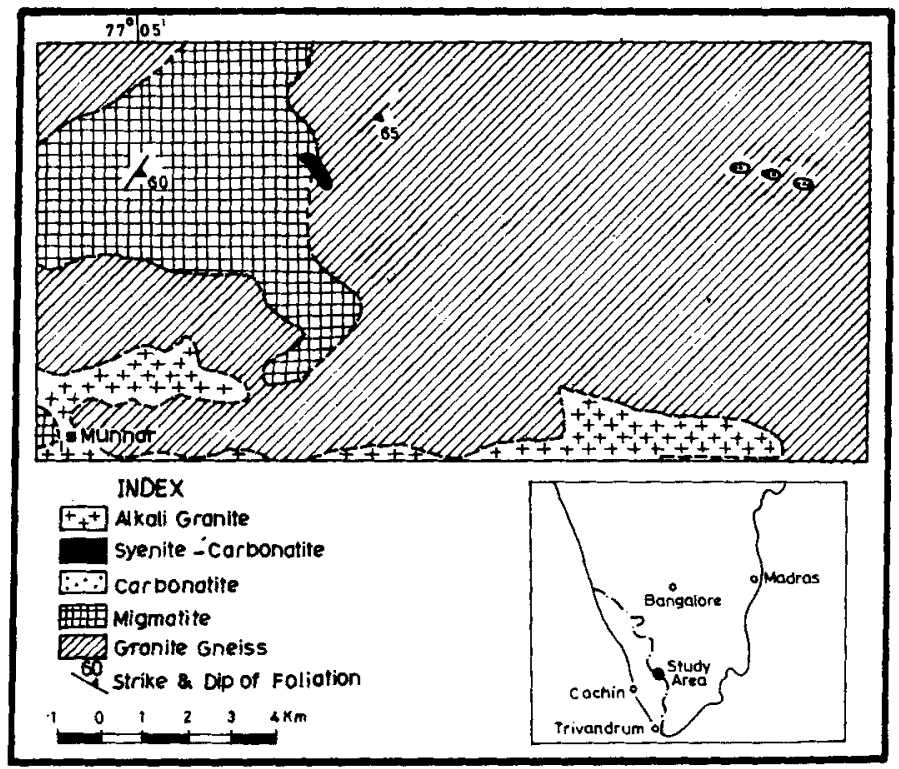

Figure 1. Geological map of Munnar area.

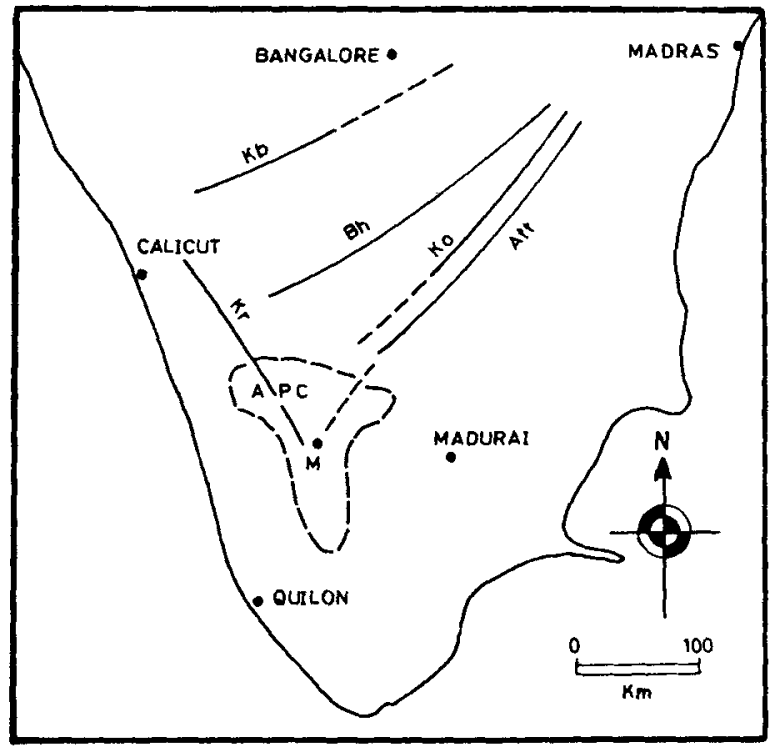

Figure 2. Relationship of the study area with regional fault-lineaments of South India (Kb--Kabbani lineament; Bh--Bhavani lineament; Ko-Koratti lineament; Att-Attur lineament; $\mathrm{Kr}$-Kerala lineament; APC-Anamalai-Palni-Cardamom massif (after Katz 1978); M-Munnar area). 
1983). The associated gneisses are of pink and grey varieties, the former bearing porphyroblastic pink feldspar and the latter having dominance of biotite. Regional foliation trends vary from WNW-ESE to E-W with northerly dips of 50 to $70^{\circ}$. The migmatites of the area incorporate minor lenses of pyroxene granulite and biotite-rich 'restite'. Recent geochronologic data (Odom 1982) assign an age of $740 \pm 30 \mathrm{~m} . \mathrm{y}$. for the granite.

Carbonatites are exposed as two minor patches. The one which occurs towards north of the study area (figure 1) is seen as patches, lenses and veins of 0.3 to $1 \mathrm{~m}$ thickness, cutting coarse grained syenite which occurs as a NW-SE elongate body. Exposures are found very near the $15 \mathrm{~km}$ point of the road from Munnar to Udumalpet. The second exposure is towards east of the area, near Ellapatty estate $24 \mathrm{~km}$ from Munnar on the road to top station where coarse-grained carbonatite occurs as lenticular bodies up to $1.5 \mathrm{~m}$ thickness within gneissic rocks. In both the localities, the carbonatite bodies show sharp and discordant margins with absence of any pseudomorphs or corroded relicts within them. Fenitisation is characterised by the development of pink K-feldspar megacrysts and coarse pyroxene laths in the country rock at the contact.

\section{Mineralogy}

The alkali granite is a massive medium-to-coarse grained rock with pink feldspar and quartz. The $\mathrm{K}$-feldspar (microcline) exhibits development of perthitic stringers. Plagioclase occurs as subhedral laths showing lamellar twinning and corresponds to albite-oligoclase in composition. Quartz is generally anhedral. Biotite, sphene, apatite and zircon are the major accessories. The opaque is represented by magnetite. Modal analyses show an average of $21.5 \%$ quartz, 60.3\% alkali feldspar and $12.1 \%$ plagioclase (Nair et al 1983).

The syenite is leucocratic and coarse-grained with feldspar and pyroxene as the principal minerals. In thin section, an assemblage of microperthitic K-feldspar, augite and minor aegirine augite, subordinate sodic plagioclase, alkali amphibole and biotite is seen. Primary calcite occurs commonly filling interstices or as veins. Apatite, sphene and zircon occur in accessory amounts.

The carbonatites are fresh and homogeneous and represent two varieties. A coarsegrained holocrystalline type having yellowish calcite crystals constituting $90 \%$ of the rock, with pyroxene, apatite and magnetite correspond to sovite (Streckeisen 1979). The second variety which contains highly coarse calcite crystals (up to $1 \mathrm{~cm}$ ) and associated dolomite with mafic minerals constituting $30 \%$ of the rock corresponds to alvikite. The sovite exhibits an interlocking crystals mosaic of calcite in thin-section and the individual crystals exhibit polysynthetic twinning. The calcite crystals of alvikite show exsolution blebs of dolomite. The major mafic component in both the varieties is aegirine augite which forms euhedral to subhedral laths. The opaque phase is dominantly magnetite. Rarely, phlogopite, biotite and minor laths of albite are also noted. Small crystals of euhedral apatite are found occluded in the calcite grains.

\section{Geochemistry}

The analytical results of four carbonatite samples are given in table 1 and those of two syenite samples and the average data of seven alakali granite samples in table 2. 
Table 1. Major and trace elements data of carbonatites from Munnar.

\begin{tabular}{|c|c|c|c|c|}
\hline & M-15 & M-18 & M-39 & M-40 \\
\hline \multicolumn{5}{|c|}{ Major elements wt $\%$} \\
\hline $\mathrm{SiO}_{2}$ & $17 \cdot 21$ & 9.99 & $17 \cdot 33$ & $16-68$ \\
\hline $\mathrm{Al}_{2} \mathrm{O}_{3}$ & $2 \cdot 60$ & $2 \cdot 55$ & 3.06 & $3 \cdot 57$ \\
\hline $\mathrm{TiO}_{2}$ & $0-11$ & 0.08 & 0.17 & 0.09 \\
\hline $\mathrm{Fe}_{2} \mathrm{O}_{3}$ & 0.08 & 0.04 & $0-03$ & 0.04 \\
\hline $\mathrm{FeO}$ & 0.72 & 1.08 & $0-93$ & 1.08 \\
\hline $\mathrm{MnO}$ & $0-03$ & 0.04 & $0-04$ & 0.04 \\
\hline $\mathbf{M g O}$ & $0-80$ & 0.80 & $1 \cdot 60$ & $1 \cdot 20$ \\
\hline $\mathrm{CaO}$ & $49 \cdot 28$ & 50.40 & $43-69$ & $44 \cdot 80$ \\
\hline $\mathrm{Na}_{2} \mathrm{O}$ & $0-50$ & 0.23 & $0-25$ & $0 \cdot 31$ \\
\hline $\mathrm{K}_{2} \mathrm{O}$ & $0-58$ & 0.01 & $0-57$ & 0.02 \\
\hline $\mathrm{P}_{2} \mathrm{O}_{5}$ & $0-09$ & 0.09 & $0-04$ & $0 \cdot 02$ \\
\hline Moisture & $0-09$ & 0.13 & 0.21 & 0.09 \\
\hline L.O.I. & $27 \cdot 87$ & $34 \cdot 41$ & $31 \cdot 61$ & $31 \cdot 70$ \\
\hline \multicolumn{5}{|c|}{ Trace Elements, ppm. } \\
\hline $\mathbf{A g}$ & 5 & 4 & 3 & 11 \\
\hline B & 160 & 190 & 90 & 100 \\
\hline $\mathrm{Ba}$ & 164 & 78 & 233 & 16 \\
\hline $\mathbf{B i}$ & 50 & 62 & 43 & 51 \\
\hline Co & 23 & 22 & 19 & 19 \\
\hline $\mathrm{Cr}$ & 57 & 83 & 120 & 94 \\
\hline $\mathrm{Cu}$ & 8 & 10 & 8 & 6 \\
\hline $\mathbf{L i}$ & 4 & 4 & 4 & 3 \\
\hline $\mathrm{Ni}$ & 33 & 64 & 59 & 61 \\
\hline $\mathrm{Pb}$ & 68 & 62 & 43 & 51 \\
\hline $\mathbf{R} \mathbf{b}$ & 10 & 11 & 37 & 38 \\
\hline Sr & 107 & 553 & 105 & 307 \\
\hline $\mathbf{Y}$ & 17 & 17 & 19 & 19 \\
\hline $\mathrm{Zn}$ & 26 & 26 & 22 & 21 \\
\hline $\mathrm{Zr}$ & 30 & 37 & 21 & 29 \\
\hline
\end{tabular}

Samples M-15 and M-18 from carbonatite associated with syenite; Samples M-39 and M-40 from lenticular carbonatite in gneisses.

The major elements were analysed by wet chemical methods. $\mathrm{Na}$ and $\mathrm{K}$ were determined by flame photometer. Trace elements were analysed by atomic absorption spectrophotometer (Perkin-Elmer 4000). Y and Zr were determined by XRF.

General geochemical features of the carbonatites include high levels of $\mathrm{SiO}_{2}$ (av. 15.3), $\mathrm{Al}_{2} \mathrm{O}_{3}$ (av. 2.95) and $\mathrm{CaO}$ (av. 47.04) and low levels of $\mathrm{TiO}_{2}$ (av. 0.11), $\mathrm{Fe}_{2} \mathrm{O}_{3}(0.06), \mathrm{MgO}$ (av. 1-10) and $\mathrm{P}_{2} \mathrm{O}_{5}(0.06)$. Based on the chemical classification recently proposed by Woolley (1982), the plots of the carbonatites in the ternary, $\mathrm{CaO}-\mathrm{MgO}-\mathrm{Fe}_{2} \mathrm{O}_{3}+\mathrm{FeO}+\mathrm{MnO}$ (figure 3) fall in the field of sovite/alvikite.

A comparison of the mean content of some oxides and elements in the Munnar carbonatite with those of sovite, alvikite, typical carbonatite (mean as well as range) and sedimentary carbonate rocks is presented in table 3. Overall, the element concentrations are comparable with those of sovite and alvikite and fall within the spectrum of typical carbonatites. Higher contents of trace elements like Co (av. $20.8 \mathrm{ppm}$ ), $\mathrm{Cr}$ (av. $88.5 \mathrm{ppm}$ ), $\mathrm{Ni}$ (av. $54.3 \mathrm{ppm}$ ) and $\mathrm{Pb}$ (av. $56 \mathrm{ppm}$ ) than that of sedimentary carbonates $(0 \cdot 1,11,20$ and 9 ppm respectively) are characteristic. However, the $\mathrm{Ba}$ (av. $122.8 \mathrm{ppm}$ ) and $\mathrm{Sr}$ (av. $268 \mathrm{ppm}$ ) values are low, compared to similar values 
Table 2. Major and trace elements data of syenite and alkali granite of Munnar.

\begin{tabular}{|c|c|c|c|c|}
\hline & M-14 & M-17 & Mean (1) & MRG \\
\hline \multicolumn{5}{|c|}{ Major elements, wt. \% } \\
\hline $\mathrm{SiO}_{2}$ & $60 \cdot 32$ & 60.94 & $60-63$ & $71 \cdot 34$ \\
\hline $\mathrm{Al}_{2} \mathrm{O}_{3}$ & $14 \cdot 79$ & $15 \cdot 81$ & $15 \cdot 30$ & 13.84 \\
\hline $\mathrm{TiO}_{2}$ & 1.07 & 1.01 & 1.04 & 0.24 \\
\hline $\mathrm{Fe}_{2} \mathrm{O}_{3}$ & 0.91 & $1 \cdot 24$ & 1.08 & 1.68 \\
\hline $\mathrm{FeO}$ & $2 \cdot 77$ & $2 \cdot 19$ & 2.48 & $0-84$ \\
\hline $\mathrm{MnO}$ & 0.05 & 0.09 & $0-07$ & 0.02 \\
\hline $\mathrm{MgO}$ & 1.44 & $1 \cdot 28$ & 1.36 & 0.66 \\
\hline $\mathrm{CaO}$ & 7.84 & $6 \cdot 27$ & 7.06 & $1 \cdot 70$ \\
\hline $\mathrm{Na}_{2} \mathrm{O}$ & $2 \cdot 15$ & $2 \cdot 70$ & $2 \cdot 43$ & $2 \cdot 56$ \\
\hline $\mathrm{K}_{2} \mathrm{O}$ & $7 \cdot 14$ & $6 \cdot 10$ & 6.62 & 5.66 \\
\hline $\mathrm{P}_{2} \mathrm{O}_{3}$ & 0.08 & 0.09 & 0.09 & 0.02 \\
\hline Moisture & 0.14 & $0 \cdot 19$ & 0.17 & 0.14 \\
\hline L.O.I. & 0.60 & $1 \cdot 37$ & 0.99 & 0.50 \\
\hline $\mathrm{K}_{2} \mathrm{O} / \mathrm{Na}_{2} \mathrm{O}$ & $3 \cdot 32$ & $2 \cdot 26$ & $2 \cdot 79$ & $2 \cdot 21$ \\
\hline $\mathrm{K}_{2} \mathrm{O} / \mathrm{CaO}$ & 0.91 & 0.97 & 0.94 & $3 \cdot 33$ \\
\hline $\mathrm{K}_{2} \mathrm{O} / \mathrm{MgO}$ & $4 \cdot 96$ & $4 \cdot 77$ & 4.87 & 8.58 \\
\hline $\begin{array}{l}\mathrm{Fe}_{2} \mathrm{O}_{3} / \mathrm{FeO} \\
\text { Trace elemen }\end{array}$ & 0.34 & 0.57 & 0.45 & 1.97 \\
\hline $\mathbf{A g}$ & 2 & 2 & 2 & .. \\
\hline B & 160 & 120 & 140 & 110 \\
\hline $\mathrm{Ba}$ & 1383 & 655 & 1119 & 233 \\
\hline $\mathrm{Bi}$ & 28 & 61 & 445 & 41 \\
\hline Co & 21 & 24 & 235 & 15 \\
\hline $\mathrm{Cr}$ & 334 & 432 & 383 & 288 \\
\hline $\mathrm{Cu}$ & 13 & 9 & 11 & 10 \\
\hline $\mathbf{L i}$ & 5 & 6 & 5.5 & 7 \\
\hline $\mathrm{Ni}$ & 110 & 115 & 112.5 & 99 \\
\hline $\mathbf{P b}$ & 51 & 45 & 48 & 53 \\
\hline $\mathbf{R} \mathbf{b}$ & 173 & 216 & 194.5 & $\ldots$ \\
\hline $\mathrm{Sr}$ & 385 & 339 & 362 & 233 \\
\hline $\mathbf{Y}$ & 22 & 23 & $22 \cdot 5$ & . \\
\hline $\mathrm{Zn}$ & 55 & 25 & 40 & 45 \\
\hline $\mathrm{Zr}$ & 76 & 78 & 77 & . \\
\hline $\mathrm{K} / \mathrm{Ba}$ & 37.5 & $77 \cdot 3$ & 57.4 & $201 \cdot 7$ \\
\hline $\mathbf{K} / \mathbf{R b}$ & $342 \cdot 8$ & $234 \cdot 3$ & 288.6 & . \\
\hline $\mathrm{Ba} / \mathrm{Sr}$ & $4 \cdot 1$ & 1.9 & 3 & 1.0 \\
\hline $\mathbf{R b} / \mathbf{S r}$ & 0.45 & 0.64 & 0.55 & . \\
\hline
\end{tabular}

Mean (1)-Average of two syenite analyses of present study. MRG-Mean analysis of seven samples of the alkali granite (after Nair et al 1983).

reported for corbonatites of the Nellore schist belt, (Vasudevan et al 1977). Considerable variability in geochemical features among the carbonatite complexes in different localities of south-west Asia has been observed (e.g. Deans and Powell 1968). In the present case, the contrast in geochemistry, especially the trace element characters like low $\mathrm{Ba}$ and $\mathrm{Sr}$ levels and high $\mathrm{Ni}$ and $\mathrm{Cr}$ levels are assumed to result from peculiar petrogenetic history as discussed later.

The mean $\mathrm{SiO}_{2}(60-63)$ and $\mathrm{Al}_{2} \mathrm{O}_{3}(15 \cdot 3)$ levels of the associated syenite (table 2) are comparable with those of other alkali syenites of Kerala. The higher $\mathrm{K}_{2} \mathrm{O} / \mathrm{MgO}$ (av. 4.87) are also similar. The high $\mathrm{CaO}$ values (av. 7.06) are however, unique and 


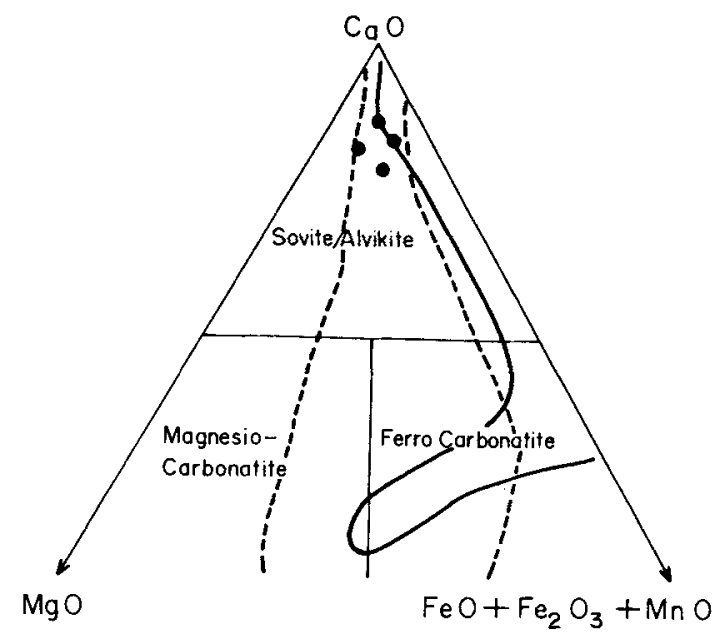

Figure 3. $\mathrm{CaO}-\mathrm{MgO}-\mathrm{FeO}+\mathrm{Fe}_{2} \mathrm{O}_{3}+\mathrm{MnO}$ plots of the carbonatites. The thick line represents the field of Thundulu carbonatites and the broken line represents the field of Alno carbonatites (after Woolley 1982).

Table 3. Salient geochemical features of Munnar carbonatite compared with data on other carbonatites (oxides in weight per cent and elements in ppm).

\begin{tabular}{|c|c|c|c|c|c|c|}
\hline & Mean (1) & Sovite & Alvikite & Mean (2) & Range & Mean (3) \\
\hline $\mathrm{Fe}_{2} \mathrm{O}_{3}$ & $0-06$ & $0.4-2.7$ & $0.8-5.9$ & $3 \cdot 12$ & $\mathrm{tr}-38.88$ & 0.54 \\
\hline $\mathrm{MnO}$ & $0-04$ & $0.1-0.82$ & $0.54-1.9$ & 0.61 & $\operatorname{tr}-8.60$ & 0.14 \\
\hline $\mathrm{MgO}$ & $1 \cdot 10$ & $<0.1-0.4$ & $<0.1-0.4$ & 5.64 & $\mathrm{tr}-42.68$ & $7 \cdot 79$ \\
\hline $\mathrm{TiO}_{2}$ & 0.11 & $<0.1-0.1$ & $<0.1-1.0$ & 0.80 & $\operatorname{tr}-5 \cdot 20$ & $0-07$ \\
\hline $\mathrm{Ba}$ & 122.8 & $360-3280$ & $465-3280$ & 2600 & $\mathrm{tr}-69000$ & 8.9 \\
\hline Co & 20.8 & $<5$ & $<5$ & 17 & $0-130$ & $0-1$ \\
\hline $\mathrm{Cr}$ & 88.5 & $5-12$ & $5-20$ & 48 & $0-1360$ & 11 \\
\hline $\mathrm{Cu}$ & 8 & $<5$ & $<5-10$ & 2.5 & $0-1461$ & 4 \\
\hline $\mathrm{Li}$ & 3.8 & $20-55$ & $5-55$ & - & $0-100$ & 5 \\
\hline $\mathbf{N i}$ & $54 \cdot 3$ & $<5-35$ & $<5-55$ & 8 & $0-280$ & 20 \\
\hline $\mathbf{P b}$ & 56 & $<10$ & $<10-61$ & - & $0-700$ & 9 \\
\hline Sr & 268 & $745-1860$ & $560-1145$ & 4000 & $\operatorname{tr}-154000$ & $592 \cdot 3$ \\
\hline $\mathbf{Y}$ & 18 & $<10-110$ & $<10-118$ & 96 & $0-1000$ & 30 \\
\hline
\end{tabular}

Mean (1)-Average of 4 carbonatite analyses of present study; Sovite and alvikite analyses from Barber (1974); Mean (2)-Typical carbonatite composition from Gold (1963); Range-Range of abundances in carbonatites (after Gold 1966); Mean (3)-Average of sedimentary carbonates (after Turekian and Wedepohl 1961).

correspond to the ubiquitous association of primary calcite in the syenite. $\mathrm{Fe}_{2} \mathrm{O}_{3} / \mathrm{FeO}$ rates are rather low (av. 0.45 ) indicative of low oxygen fugacities during crystallization. As the syenite crystallized from an alkali silicate melt enriched with $\mathrm{CO}_{2}$ (as discussed later), $\mathrm{CO}_{2}$-partial pressure seems to have been dominant.

The granite shows an average of $73.34 \mathrm{SiO}_{2}$ and $13.84 \mathrm{Al}_{2} \mathrm{O}_{3} \cdot \mathrm{K}_{2} \mathrm{O}$ values are high (av. 5.66) yielding higher $\mathrm{K}_{2} \mathrm{O} / \mathrm{Na}_{2} \mathrm{O}$ (av. 2.21), $\mathrm{K}_{2} \mathrm{O} / \mathrm{CaO}$ (av. 333) and $\mathrm{K}_{2} \mathrm{O} / \mathrm{MgO}$ (av. 8.58) ratio. Plots of $\log _{10}\left(\mathrm{~K}_{2} \mathrm{O} / \mathrm{MgO}\right)$ vs $\mathrm{SiO}_{2}$ (after Rogers and Greenberg 1981) 
fall in the alkali granite field (figure 4). $\mathrm{Fe}_{2} \mathrm{O}_{3} / \mathrm{FeO}$ ratios are high (av. 1.94) and comparable with those of I-type granites (Chapell and White 1974). Detailed geochemical studies of the alkali granite were reported earlier (Nair et al 1983) based on which a mantle-derivation is suggested.

\section{Petrogenesis}

Although alkaline complexes with carbonatite and syenite (Maravic and Morteani 1980) occurring in the Archean granulite facies of shield areas and genetically related to rifting (Hansen 1980) are widely recognised, the association alkali granite-syenitecarbonatite of Munnar devoid of related mafic differentiates like gabbros or lamprophyres may be considered unique. As the carbonatite bodies are homogeneous with complete absence of pseudomorphs or corroded relicts (Heinrich 1966), a metasomatic origin is not suggested. Moreover, the veins and lenses are sharp and discordant and the mineral assemblage is suggestive of a magmatic parentage.

The lack of enrichment in $\mathrm{P}, \mathrm{Ba}, \mathrm{Sr}, \mathrm{Zr}$ and $\mathrm{Y}$ and the absence of rare metals in the carbonatite imply that the rock was probably not derived from a primary carbonatite magma. The less evolved nature as depicted by relatively higher contents of transition elements (e.g. Ni-av. $54.3 \mathrm{ppm}, \mathrm{Cr}$-av. $88.5 \mathrm{ppm}$ ) and the lower levels of incompatible elements (e.g. Rb-av. $24 \mathrm{ppm}$; Y-av. $18 \mathrm{ppm}$ ) also substantiate this. Moreover, the volume of carbonatite and syenite is relatively low to account for an exclusive carbonate magmatism. Detailed petrochemical studies of the associated alkali granite showed that it was derived from an alkali-silicate magma generated at mantle depths (Nair et al 1983).

Liquid immiscibility between $\mathrm{CO}_{2}$ rich and silicate liquid is well established from investigations of the $\mathrm{Ab}-\mathrm{An}-\mathrm{Na}_{2} \mathrm{CO}_{3}-\mathrm{H}_{2} \mathrm{O}$ system (Koster van Groos and Wyllie

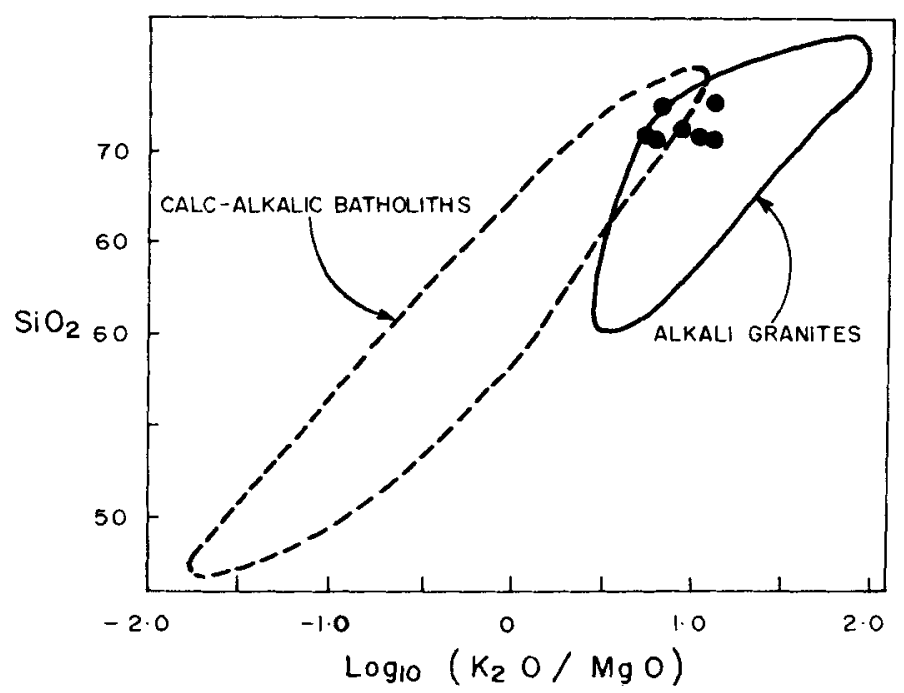

Figure 4. $\mathrm{SiO}_{2}$ vs $\log _{10}\left(\mathrm{~K}_{2} \mathrm{O} / \mathrm{MgO}\right)$ plots (after Rogers and Greenberg 1981) of the Munnar alkali granite. 
1973) and through various studies on natural examples (Roedder and Coombs 1967; Roedder 1979; Philpotts 1982). In an alkali-rich system, an immiscible carbonate-rich magma develops at some stage (Hamilton et al 1979). The immiscibility of carbonatitic and alkalic silicate liquids can be physically explained as the separation of a less viscous carbonate liquid from a more viscous polymerized silicate phase. The carbonate liquid would be lower in density because of higher content of $\mathrm{H}_{2} \mathrm{O}$ and this contrast in density could cause phase separation due to the earth's gravitational field alone (Moller et al 1980). The pre-requisite to establish separation of immiscible silicate-saturated carbonatite liquid and the associated carbonate-saturated silicate melt is achieved as follows:

Large-scale volatile outgassing occurs during crustal warping and distension prior to rifting which trigger mantle degassing (Bailey 1974). Imprints of such large-scale volatile influx is recognised in the Kerala region (cf. Nair and Santosh 1984). Rapid ascent of volatiles enriched in $\mathrm{CO}_{2}$ liberated from the mantle cause partial melting at shallower levels of the mantle, resulting in the following ion-exchange reaction (Moller et al 1980):

$$
\begin{aligned}
& \mathrm{Ca}^{2+}+2(\mathrm{~K}, \mathrm{Na}) \mathrm{AlSi}_{3} \mathrm{O}_{8} \text { (alkali feldspar) }+4 \mathrm{Mg}_{2} \mathrm{SiO}_{4} \text { (olivine) } \\
& =2(\mathrm{~K}, \mathrm{Na})^{+}+\mathrm{CaAl}_{2} \mathrm{Si}_{3} \mathrm{O}_{8} \text { (plagioclase) }+8 \mathrm{Mg} \mathrm{SiO}_{3} \text { (pyroxene). }
\end{aligned}
$$

Alkali metals are subsequently introduced into the carbonate liquid. This fixes the $\mathrm{CO}_{2}$ partial pressure, thus preventing $\mathrm{Ca}^{2+}$ ions from crystallizing as plagioclase and polymerizes the ortho-silicate ions. The high potassic nature and other geochemical characters of the associated syenites imply melt equilibration from a phlogopite bearing peridotite at depths exceeding $120 \mathrm{~km}$ as the peridotite solidus crosses the continental geotherm at these depths (Harris et al 1983). Phlogopite-rich pockets have been proposed for the origin of other similar syenites from Kerala (Nair and Santosh 1984). The concentration of alkalies and $\mathrm{CO}_{2}$ in the alkali silicate melt increased and subsequent cooling and ascent of the magma led to the separation of an immiscible fraction (Mysen 1975). A fingerprint of this carbonate and silicate-liquid immiscibility is preserved in the form of primary calcite in both the alkali granite and the syenite.

From the same liquid composition, calcite is precipitated at lower pressures and dolomite, ankerite and siderite at higher pressures (Wyllie and Biggar 1966). The alvikite carbonatite occurring as lenses and patches within the syenite has an association of calcite and dolomite. This variety crystallized at slightly elevated pressures together with the associated syenite. The sovite carbonatite, occurring within gneisses, however, represents the ultimate fraction which crystallized at lower pressures, presumably due to the higher level of emplacement controlled by the lineament.

The perpotassic nature of the associated syenites, with ubiquitous association of primary carbonate and aegirine is comparable with the orthoclasite fenite described from Sudan (Harris et al 1983). In the second locality, fenitisation is restricted to the development of K-feldspar megacrysts and laths of aegirine. Similar phenomena are reported by Verwoerd (1967) from the fenitised aureoles of South African carbonatites. Concentration of $\mathbf{K}$ in $\mathbf{K}$-feldspar and their recrystallization is a general mineralogical tendency of fenitisation (Heinrich 1966). 


\title{
6. Tectonic significance
}

Carbonatites and other alkaline complexes are, in general absent in orgenic belts and are confined to stable continental platforms. They are mostly related to vertical movements in the earth's crust and occur in regions of lithospheric rifting. Examples include the East African carbonatites which are confined to narrow zones of rift faults (De Kun 1971) and the carbonatite complexes of India which occur along deep-seated faults (Katz 1978; Sethna 1974).

Alkaline magmatism is established as a precursor to rift tectonics and is especially important in the early stages of tensional tectonics (Bailey 1974). The Munnar alkaline complex occur along the intersection zone of the Madurai and Kerala aulacogenes made up of the NE Palni arm, Ns Cardamom arm and the Nw Anamalai arm. Katz (1978) considered a triple point junction at the aulacogene stage probably manifesting a hotspot formed as a resultant tensional wedge due to NE dextral/NW sinistral interaction. The alkaline complex is thus obviously related to a distensional tectonic regime.

The alkali granite has recently been dated to be of $740 \pm 30$ my (Odom 1982). Interestingly, the carbonatites of the adjacent terrane, namely the Sevathur and Jokipatti in Tamil Nadu are dated to be of $720 \pm 30$ m.y. (Udas 1971). It is thus revealed that the southern part of the Indian shield evidenced an episode of alkaline magmatism during the late Precambrian times related to the pre-rift tectonics of the continent.

\section{Acknowledgements}

The study forms part of cESs Project, R.A.D.-4. The authors are grateful to the Director, Centre for Earth Science Studies, for facilities.

\section{References}

\author{
Bailey D K 1974 in The alkaline rocks (ed) H Sorenson (New York: John Wiley) 148 \\ Barber C 1974 Lithos 753 \\ Borodin L S, Gopal V, Moralev V M, Subramonian V and Ponikarov V 1971 J. Geol. Soc. India 12101 \\ Chappell B W and White A J R 1974 Pac. Geol. 8173 \\ Deans T and Powell J L 1968 Nature (London) 218750 \\ De Kun N 1961 Neues Jahrb. Mineral Monatsh. 6124 \\ Eckermann H 1961 Bull. Geol. Inst. Univ. Uppsala 111 \\ Gold D P 1963 Econ. Geol. 58988 \\ Gold D P 1966 Miner. Soc. India, IMA volume, 83 \\ Hamilton D L, Freestone I C, Dowson J B and Donaldson C J 1979 Nature (London) 27952 \\ Hansen K 1980 Lithos 13145 \\ Harris N B W, Mohammed A E R O and Shaddad M Z 1983 Geol. Mag. 120115 \\ Heinrich E W 1966 The geology of carbonatites (Chicago: Rand McNally) 555 p. \\ Heinrich E W and Dahlem D H 1966 Miner. Soc. India, IMA Vol. 37 \\ Katz M B 1978 J. Geol. Soc. India 19185 \\ Koster van Groos A G and Wyllie P J 1973 Am. J. Sci. 273465 \\ Maravic H and Morteani G 1980 Lithos 13159 \\ Moller P, Morteani G and Schley F 1980 Lithos 3171 \\ Mysen B O 1975 Yb. Carnegie Instn. Wash. 74454 \\ Nair N G K and Santosh M 1984 J. Geol. Soc. India 2535 \\ Nair N G K, Santosh M and Thampi P K 1983 Neues Jahrb. Mineral. Abh. 148 223-232 \\ Odom A L 1982 Final Rep. U.N. Case 81-10084
}


Phadke A V and Jhingran A G 1968 Geol. Soc. India 9165

Philpotts A R 1982 Contrib. Mineral. Petrol. 80201

Roedder E 1979 in The evolution of the igneous rocks (ed.) H S Yoder Jr. (Princeton: University Press) 15

Roedder E and Coombs D S 1967 J. Petrol. 8417

Rogers J J W and Greenberg J K 1981 Geol. Soc. Am. Bull. 9257

Sethna 1974 J. Geol. Soc. India 15429

Streckeisen A L 1979 Neues Jahrb. Mineral. Abh. 1341

Sukheswala R N and Udas G R 1964 Rep XII Int. Geol. Cong. Sec. 71

Turekian K K and Wedepohl K H 1961 Bull. Geol. Soc. Am. 72175

Udas G R 1971 Bull. Volcan. 35799

Udas G R and Krishnamurthy P 1970 Proc. Indian Natl. Sci. Acad. A36 331

Vasudevan D, Rao T M and Kota Reddy 1977 J. Geol. Soc. India 18515

Verwoerd W J 1967 Geol. Surv. S. Africa Dep. Mines Handb. 6452

Woolley A R 1982 Mineral. Mag. 4613

Wyllie P J and Biggar G M 1966 Miner. Soc. India, IMA Vol. 92 